Jurnal Ekonomi Pembangunan, 18 (2), 2017, 183-193

\title{
INDONESIAN BANKING EFFICIENCY: TRANSMISSION TO THE FINANCIAL STABILITY CONFRONTING ASEAN ECONOMIC COMMUNITY
}

\author{
Shochrul Rohmatul Ajija ${ }^{1 *}$, Mohammad Zeqi Yasin ${ }^{2}$, and Reno Albra ${ }^{3}$ \\ ${ }^{1,2,3}$ Faculty of Economics and Business, Airlangga University \\ *Corresponding Author: shochrul-r-a@feb.unair.ac.id
}

Recieved: August 2017 | Revised: November 2017 | Accepted: November 2017

\begin{abstract}
Banks are a particular type of institution within the financial system that have influence on financial stability. Their readiness will determine the government's policy, notably in an economic era of integration. In the case of South East Asia, there is the ASEAN Economic Community (AEC) which facilitates economic integration to strengthen allthe member countries. This study aims to measure bank efficiency (conventional and shariah) in Indonesia, and also establish the transmission scheme based on the estimated result through financial stability issues confronting the AEC. Data Envelopment Analysis (DEA) is used to estimate banking efficiency statically and dynamically (Malmquist Index). The result showed that technical efficiency of conventional banks is statically better than shariah banks. Meanwhile, dynamically, considering technological index, both types of banks have good results. The optimizing effort by each bank in order to increase their input utilization can be maintained through intensification of the financial program and making it more comprehensive. Subsequently, this effort hopefully can increase the number of financial participants. Eventually, increasing the number of participants will strengthen the financial stability of Indonesia.
\end{abstract}

Keywords: Banking; Efficiency; Financial Stability; AEC

JEL Classification: E50, G14, O16

How to cite: Ajija, S., Yasin, M., \& Albra, R. (2017). Indonesian Banking Efficiency: Transmission to the Financial Stability Confronting ASEAN Economic Community. Jurnal Ekonomi Pembangunan: Kajian Masalah Ekonomi dan Pembangunan, 18(2), 42-52. doi:https://doi.org/10.23917/jep.v18i2.5095

DOI: https://doi.org/10.23917/jep.v18i2.5095

\section{Introduction}

The ASEAN Economic Community (AEC) defined as the economic integration body formed among the countries in South East Asia (Wangke, 2014). Since 1997 in the ASEAN Leader Summit, it was dedicated to be concerned with the socioeconomic aspects of the prosperous, highly competitive region, as well as to ensure equitable economic development and poverty reduction. Subsequently, several advanced meetings had been held, viz., in 2003 in Bali and 2006 in Kuala Lumpur. Eventually, it was crystalized to be the
AEC agreement by 2015. This agreement will be regionalization of Southeast Asia to promoting international trades in good and services by means of free trade areas, custom unions, and other preferential trade arrangements (Sesrtcic, 2000).

Approaching this deal, each country attempted to intensify development in all sectors they had within their economies, for instance, the financial and banking sector which has made great contributions toward development in South East Asia. Figures are depicted in Figure 1 below. 









